\title{
Minimum income protection in the austerity tide
}

Sarah Marchal ${ }^{1 *}$, Ive Marx² and Natascha Van Mechelen ${ }^{3}$

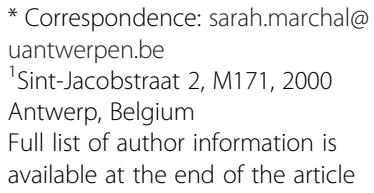

* Correspondence: sarah.marchal@ uantwerpen.be

${ }^{1}$ Sint-Jacobstraat 2, M171, 2000

Antwerp, Belgium

Full list of author information is

available at the end of the article

\begin{abstract}
Scholarly literature is inconclusive on how economic crises impact on minimum income protection. Earlier studies found small increases in the generosity of safety nets at the onset of the crisis. Yet an increased focus on budget austerity substantially altered the social policy context. This paper assesses how minimum income floors weathered the austerity tide following the crisis using purpose-collected data for 23 EU countries. Generally, social assistance benefit trends did not deviate much from pre-crisis growth levels. Yet retrenchment did occur through more technical measures, the combined impact of which was quite significant in some countries.

Jel codes: 1380

Keywords: Minimum income schemes, Crisis measures, Reforms, EU member states, Social floor
\end{abstract}

\section{Introduction}

This article looks at what $23 \mathrm{EU}$ countries undertook in the crucial area of minimum income protection (MIP) for able-bodied persons at working age during the first 5 years of what Jenkins et al. (2013) have dubbed the 'Great Recession', with a particular focus on the period when austerity started to take hold. This article follows up on Marchal et al. (2014a), in which we assessed how MIP schemes weathered the onset and initial phase of the crisis. That article started from the observation that just prior to the crisis social safety nets were not in the best of shape in Europe. Minimum income provisions had by and large deteriorated during the two decades preceding the crisis, as social policy in many EU countries had come to rest on the idea that work offered the best way out of poverty. Suddenly confronted with unemployment levels not seen in a generation, the relevance of adequate protection arrangements acquired a new level of significance.

We did find evidence of efforts to raise the social floor right after the onset of the crisis, a finding also confirmed for other fields of the welfare state (see, e.g. Marchal et al. 2014a; Clasen et al. 2012; Gauthier 2010; International Labour Organization, World Bank 2012; Isik-Dikmelik 2012; Vis et al. 2011). Yet the size of these increases did not point towards a sea change in MIP policies. All in all, these first supportive measures seemed relatively short-lived, as additional efforts became rarer from the end of 2009 onwards. Meanwhile, soaring national debts had harsh impacts on countries' finances and their position on financial markets. A hesitant recovery proved short-lived, a

C 2016 Marchal et al. Open Access This article is distributed under the terms of the Creative Commons Attribution 4.0 International License (http://creativecommons.org/licenses/by/4.0/), which permits unrestricted use, distribution, and reproduction in any medium, provided you give appropriate credit to the original author(s) and the source, provide a link to the Creative Commons license, and indicate if changes were made. 
double-dip recession ensued and EU countries were confronted with prolonged low, or in some cases negative growth rates. Countries that had to apply for financial support had to follow stringent austerity trajectories. Also elsewhere, European governments were concerned with reducing debts and deficits while EU budgetary control strengthened, through the Excessive Deficit and Macro-Economic Imbalances Procedures.

In this paper, we focus on what happened to MIP in the later stage of the crisis, as the austerity tide washed over Europe. In Marchal et al. (2014a), we hypothesized that the changes for the better would be short-lived, as budget austerity was already looming on the horizon. Here, we test that conjecture. This research question is relevant in its own right as social indicators show a continuing need for income replacement and protection benefits (Eurostat 2015). MIP schemes, in the shape of means-tested social assistance benefits, play a key role in preventing severe financial hardship when markets fail and when social security rights are not available, inadequate or depleted. In addition, we know little about changes to MIP schemes and-more generally-social floors. Whereas some authors consider these schemes to be more prone to retrenchment due to their vulnerable target group (Korpi and Palme 1998; Nelson 2007), others hold that given their small budgetary impact and enormous social relevance, social floors will be relatively untouched (Pierson 1994, 1996). Interestingly, this latter position seems to be confirmed by some of the major players within austerity-ridden Europe: the European Commission and the International Monetary Fund (European Commission 2008; International Monetary Fund 2012).

The extended time frame of this paper (until 2012, 5 years into the crisis) as well as the relatively large number of countries included (23 EU countries) allow us to assess how MIP fared after the initial crisis shock wore off. We focus explicitly on minimum income schemes, an area that arguably offers a clear indication of the changes at the floor of the welfare state. Moreover, the declined generosity of unemployment insurance arrangements (Clasen and Clegg 2011) and the surge in nonstandard work may have increased the potential significance of minimum income schemes (Immervoll 2012). We build on purpose-collected policy data, capturing in a systematic way and in significant detail policy changes in the area of MIP as these affect generosity, accessibility and obligations.

In the next section, we provide a brief overview of the existing literature on crisis measures and social policy change, particularly in the area of MIP. The third section presents the data on which this paper is based and the analytical framework used. We proceed by presenting the measures taken in the countries of our sample and assessing these measures in a cross-temporal and cross-sectional light. Next, we discuss the overall pattern of crisis responses and assess whether some countries distinguish themselves by the type of measures they have enacted. Finally, we conclude.

\section{Theory: crisis pressures and crisis constraints}

This paper sets out to assess changes to MIP taken in the immediate aftermath of the crisis and the austerity years that followed. In the two decades prior to the crisis, minimum income provisions had by and large eroded. By the start of the crisis, minimum income provisions were largely inadequate in nearly all EU Member States (Van Mechelen and Marchal 2013). Confronted with soaring unemployment levels, the relevance of adequate protection arrangements acquired a new level of significance and 
urgency. The crisis abruptly changed the context which had allowed policy makers to either neglect or 'activate' minimum income schemes over the preceding decades. Also, it critically undermined the notion that well-functioning labour markets could be relied on to provide adequate incomes for all those capable and willing to work.

Yet the literature is not clear on the effects of crisis on social protection, and MIP in particular.

The compensation hypothesis holds that as demand for social protection increases in times of crisis, more resources will be directed towards adequate protection (Shahidi 2015). Indeed, empirical studies confirm that in the wake of the crisis, discretionary support was ubiquitous: countries initially turned towards Keynesian measures in the immediate aftermath of the crisis (Marchal et al. 2014a; Vis et al. 2011; Chung and Thewissen 2011). The European Commission and the IMF advocated fiscal stimuli and explicitly mentioned income support as a valid crisis strategy, as increases in transfers to the poor were deemed more likely to feed through in aggregate demand (European Commission 2008; Spilimbergo et al. 2008). In addition, Dolls et al. (2012) argue that discretionary support was relatively more substantial in countries where social protection was less well developed to start with.

Yet the challenges posed by the crisis varied greatly across Europe and over time. The crisis morphed from a financial crisis into a recession and then a fiscal crisis between 2007 and 2010, afterwards culminated in a Eurozone crisis (Hemerijck 2012) and, for some states, a crisis of the welfare state (Gough 2011). In a review of initial labour market policy responses in six countries, Clasen et al. (2012) stress that reactions were enacted in two phases. Initially, labour market policy was used to cushion the effects of the crisis on labour markets and workers, albeit with varying intensity. Then, generally from 2010 onwards, fiscal concerns came to the fore, although, again, to a varying extent in the six countries of their analysis. It is worth noting, however, that governments were faced with multiple challenges from the start, competing to some extent for attention and financial resources. Cost containment concerns must have played an important role even during these first years although there was not yet the acute pressure from financial markets which took centre-stage after mid-2010. Indeed, there can be little doubt that austerity later became the main theme, as it became clear that a double-dip scenario was unfolding and a prolonged period of low growth and by implication budgetary restraint would ensue. That is not to say that austerity hit the continent in equal measure. The initial effect of the crisis had been varied, but public finances were also in much better shape in some countries as opposed to others (Farnsworth and Irving 2011).

The impact of this austerity shift in more recent years is unclear. Some authors posit that small, residual schemes will survive austerity rounds relatively unscathed, given their small impact on general expenses and important social consequences (Pierson 1994). Alternatively, Korpi and Palme (1998) point towards the importance of political alliances in protecting income replacement schemes from retrenchment. In this regard, social floors are especially vulnerable, as there are no clear organized interest group alliances protecting MIP provisions.

It is therefore interesting to ask how austerity might have affected minimum income schemes in particular. These schemes act as a crucial final safety net against poverty but in budgetary terms their cost is relatively limited. Countries typically only spend a 
small percentage of GDP on final safety net provisions. Outlays on social insurance, education and health generally dwarf outlays on social assistance. Moreover, the institutions making up the infamous Troika, particularly the IMF, strongly favour 'cost-efficient' means-tested benefits, over more expensive social insurance, let alone universal provisions. It is not unthinkable that even in a context of austerity, and especially in countries under Troika pressure, social assistance was strengthened, possibly at the cost of spending on other social items, or elsewhere. A 2012 IMF Country Report on Greece did not mince words (International Monetary Fund 2012, pp. 19-20):

Left unreformed, social benefit settings could also contribute to high reservation wages, frustrating efforts to move workers out of unemployment spells. In this context, the authorities are to identify 1-2 percent of GDP in additional savings, with the focus on discontinuing non-essential programs and improving the targeting of core programs. The largest potential savings would be possible through replacing most existing programs with a single, income-tested minimum income scheme targeted at the bottom 20 percent of the income distribution (with presumptive income also used to control for evasion)

However, while strongly targeted means-tested social safety nets make up a relatively small portion of government spending and play a key role as a protection against extreme poverty, there is a political science literature line arguing that such programs are particularly vulnerable to governments under cost cutting pressures because they generally cater to particular, fragmented sections of the electorate, far removed from the all-powerful median voter (Korpi 1980; Korpi and Palme 1998). Programs most in danger of retrenchment are those where interests are least organized or articulated, as opposed to say social insurance programs with stable constituencies represented by powerful stakeholders, for example trade unions. By contrast, the populations living on social assistance tend to be fluid and geographically fragmented.

Finally, in a context of a prolonged collapse in labour demand, governments may become more strongly concerned about additional inflows into the system which not only bring additional pressures on tight budgets, but also the risk of chronic dependency and scarring further down the line.

\section{Data and analytical framework}

\subsection{Data}

In this paper, we track changes to MIP in the aftermath of the crisis. We take a broad approach to MIP: we look at the combination of benefits that guarantee the absolute social floor in each country in order to compare functional equivalent income protection benefit packages. Minimum income benefits are beyond doubt the most important component, but a substantial number of countries complement minimum income benefits with cost-compensating benefits, such as housing or heating allowances and child benefits.

To this end, this paper builds on the CSB-MIPI dataset, an expert-sourced dataset that covers in detail the institutional arrangements relating to different MIP schemes. The present paper focuses on the MIP arrangements catering for able-bodied unemployed falling outside the scope of the insurance scheme. Information is available 
for $23 \mathrm{EU}$ countries, ${ }^{1}$ since 2001. The data set includes annual time series on gross benefits as well as detailed model family simulations that grasp the interplay of various schemes and measures in providing a minimum income package to various types of households. ${ }^{2}$ It furthermore includes information on activity requirements for minimum income recipients. Most importantly for our present purposes, the 2010 and 2012 waves inquired after policy changes impacting on the minimum income benefit packages that were implemented since the onset of the crisis, gathering information on the crisis measures taken in the period 2008-January 2012. The data is provided by national experts on the basis of detailed questionnaires and instructions. Many have participated in earlier studies on social benefit packages (Bradshaw and Finch 2002; Eardley et al. 1996), or currently participate in EUROMOD. More information on the methodology and content of CSB-MIPI, as well as a list of the national experts contributing to this data set, can be found in Van Mechelen et al. (2011).

By first defining the group at risk (here the working-aged able-bodied who fall outside the social insurance scheme and are without a job), equivalent schemes are compared across countries, instead of schemes that merely have a similar name. In most European countries, this target group is catered for by the general final safety net, i.e. the minimum income scheme that provides support to all those who have passed the means test. In the United Kingdom, Ireland, Germany, Finland and Hungary however, this target group receives support from a categorical income support scheme (see Bahle et al. 2011). ${ }^{3}$ In Austria (until September 2010), Italy and Spain, the minimum income scheme is a subnational responsibility, whereas in Sweden municipalities have a large degree of autonomy. CSB-MIPI contains information for respectively the localities Vienna, Milan, Catalonia and Stockholm.

CSB-MIPI includes policy changes that impacted on the net disposable income of minimum income recipients, i.e. it includes changes in additional support if minimum income beneficiaries are entitled, even when this additional support is provided through a different scheme, as well as conditions tied to minimum income receipt implemented in the period 2008-start 2012. Ideally, we would focus on those measures taken in response to the crisis (see Marchal et al. 2014a). However, as the period under consideration is quite large, the distinction between measures that are driven by the crisis, are adjustments to a changed socio-economic context or would have been enacted anyhow, becomes more and more blurred. Therefore, this paper provides an overview of changes enacted since the onset of the crisis that were relevant for households relying on minimum income benefits. The focus is on policy changes that require actual intervention. For instance, regular uprating of the benefit based on an indexation mechanism is not included in the overview. In order to provide an overview as complete as possible, measures provided by the CSB-MIPI respondents were crosschecked with the OECD Benefits and Wages series (OECD 2011), the ILO/World Bank Inventory of policy responses to the global financial and economic crisis of 2008 (ILO/World Bank 2012) and MISSOC (2013). Where possible, we indicate in the main text where measures are especially unlikely to have been related to the crisis context, as per assessment of the respondent or evidence of a clear preparation before the onset of the crisis (and implemented without further modification or reference to the crisis) in secondary sources. This distinction is however more robust for the first crisis years. 
An important consideration is that various authors have forcefully argued that retrenchment measures are more likely to occur through less visible administrative or technical adaptations, or even through non-intervention, in order to raise less resistance (Pierson 1996). In the context of MIP, this may occur through non-interventions such as skipping indexation, or small, technical changes such as tinkering with eligibility parameters.

Our time series of gross minimum income benefits allow gauging nominal increases or standstills. We also compare trends in gross benefits to more substantively relevant denominators like prices and average wages. These, however, are influenced by other factors than policy alone.

Changing access and behavioural conditions generally require explicit legal changes, although these are often of a rather technical nature. The data employed in this paper allow in principle to capture such changes. Also in this field, creeping retrenchment is possible by not adjusting nominal eligibility thresholds. This kind of retrenchment is harder to gauge, and the data employed in this paper may fail to fully take account of this. When there is a link between the benefit levels on the one hand, and the eligibility thresholds on the other, creeping retrenchment in benefit levels may also point towards a tightening of access.

\subsection{Analytical framework: assessing changes}

We structure our assessment in line with the framework we adopted in Marchal et al. (2014a). Following Yerkes and Van der Veen (2011), we assess changes in the field of MIP from a social citizenship perspective. This perspective allows for a rather nuanced assessment of different dimensions of MIP that are relevant for its beneficiaries.

Social citizenship is constituted by social rights and obligations (Kvist 2007; Marshall 1950). According to Kvist (2007), social rights are manifested through different configurations of benefit characteristics, i.e. generosity of benefits and eligibility criteria. The generosity of benefits refers to the legally guaranteed benefit levels, whereas the eligibility criteria define the pool of persons who may access the benefit. Obvious examples of eligibility criteria are nationality and residence requirements and means tests. However, the shift of social policy measures towards activation has by now been extensively documented (Aurich 2011; Marchal and Van Mechelen 2014b; Immervoll 2012; Kenworthy 2010; Eichhorst and Konle-Seidl 2008). Obligations or behavioural requirements of beneficiaries to ensure continued benefit receipt have been strengthened and made more explicit and should therefore be taken into account when assessing changes in social citizenship.

Table 1 shows our operationalization of each of these dimensions. Two important caveats apply. First, we do not include the value of in-kind benefits and (free) services to which minimum income recipients may have access. Quantifying such measures is fraught with difficulties. First, provision is often only guaranteed at the local level, leading to large intra-national differences in presence and level. Second, their face value depends heavily on actual use that is determined by the specific characteristics of each beneficiary unit. Third, some of these measures are only discretionarily awarded, therefore not matching with a rights-based perspective.

Second, a problem that is especially relevant for assessing the conditionality of benefits is how to treat possible (and probable) discrepancies between implementation and 
Table 1 Operationalization of the dimensions of social citizenship

\begin{tabular}{|c|c|c|}
\hline \multicolumn{2}{|l|}{ Rights } & \multirow{2}{*}{$\begin{array}{l}\text { Obligations } \\
\text { Conditions for benefit receipt }\end{array}$} \\
\hline Generosity & Accessibility & \\
\hline $\begin{array}{l}\text { Trends in gross and net benefit } \\
\text { levels (nominal, real, \% average } \\
\text { wage) }\end{array}$ & $\begin{array}{l}\text { Description of policy measures impacting } \\
\text { on access/eligibility conditions (including } \\
\text { time limits) to minimum income benefits } \\
\text { and other income components }\end{array}$ & $\begin{array}{l}\text { Description of policy measures } \\
\text { impacting on the conditions } \\
\text { for benefit receipt }\end{array}$ \\
\hline $\begin{array}{l}\text { Crisis has also impacted on the } \\
\text { denominators }\end{array}$ & Trends in net benefit packages & \\
\hline \multicolumn{3}{|l|}{$\begin{array}{l}\text { Comparison with previous } \\
\text { trends in benefits allows to } \\
\text { assess hidden retrenchment }\end{array}$} \\
\hline $\begin{array}{l}\text { Description of first round crisis } \\
\text { measures impacting on other } \\
\text { income components }\end{array}$ & & \\
\hline
\end{tabular}

regulation (Clasen and Clegg 2007). Here, the focus is on statutory rights and obligations.

In this paper, we monitor legislative changes to any of these dimensions in order to assess how minimum income floors have shifted during the "age of austerity". In addition, we assess the combined impact of these legislative changes on the net disposable income for the aforementioned family types. This allows assessing the effects of the interplay of changes in generosity and access (at least to the extent the underlying assumptions of the simulations allow for detecting changes in eligibility criteria).

In line with other crisis literature, we assess whether these changes are merely parametric changes to minimum income provision, or whether they point towards a structural change. Are the institutional characteristics of MIP changed in such a way that its impact will likely be felt for years to come, on multiple dimensions and changing the underlying logic of the scheme, or do we mainly see tinkering at the margins?

\section{Changing minimum income protection schemes}

\subsection{Crisis measures affecting minimum income recipients}

This section aims to provide an overview, as complete as possible, of the different measures that impacted on the situation of social assistance beneficiaries. We identify measures or changes as relevant, as they impact on one or more of the dimensions of social citizenship (generosity, access and behavioural conditionality) guaranteed to minimum income beneficiaries.

\subsubsection{Benefit generosity}

4.1.1.1 Gross minimum income benefit levels In the pre-crisis period, nominal gross benefits generally increased, as most countries (either or not automatically) adjust gross benefits levels for price rises at regular intervals (Van Mechelen 2013). There are only a few exceptions (Ireland, Bulgaria, Estonia, Lithuania, Latvia and the Slovak Republic). However, in most of these countries, governments did in fact issue periodic increases in the years before the crisis. Significant nominal decreases of gross benefit rates were rare and occurred only in the Czech and the Slovak Republic. Both were part of farreaching reforms of the social safety net. 
During the first crisis year(s), nominal growth rates did not slow down (see Fig. 1). In 2008-2009 (coinciding with the brunt of fiscal stimulus programs), benefit levels in fact increased, in over half of the countries of our sample, exceeding the average increases during the pre-crisis period.

Growth rates decelerated and even halted later on in the crisis. This is especially the case in those countries without indexation mechanism. However, a substantial number of countries also skipped indexation (see Table 2). In some cases, this was a consequence of low inflation, especially in Sweden and Finland. In the latter country, skipping indexation in 2010 actually meant a real increase of benefit levels. Moreover, Finland subsequently implemented a substantial raise in minimum income benefits. In Germany, low inflation triggered in 2010 a 'Schutzklausel' that protects certain benefits from a nominal decrease when inflation is negative. Yet in other countries skipping indexation should be understood as an austerity measure. This was the case in Romania, Slovenia, the Slovak Republic, Portugal and Spain. Moreover, in a number of countries, indexation mechanisms changed, leading to a (presumably) less generous indexation, for instance in Germany and the United Kingdom in 2011. An exceptional development occurred in Ireland, where minimum income benefits were actually cut by around $4 \%$. Also in Portugal, the gross benefit for a couple decreased, as part of a far-reaching reform of the minimum income scheme. In Italy (Milan), minimum income benefits depend on the available budget and on social workers' assessment of the situation. As the crisis gained foothold, the (estimated) actually awarded benefit amounts decreased. Finally, Hungary cut base rates by $20 \%$. It should be noted that similar nominal decreases were rather exceptional in the years before the crisis.

Many of the nominal increases observed in the first crisis years translate in substantial real hikes in most countries. This is partially due to the lagged reaction of indexation mechanisms to in some cases quite substantial pre-crisis increases in consumer prices. Yet these automatic increases were further reinforced by additional increases of gross benefits in a substantial number of countries (see Table 2). Later on, the deceleration in nominal growth or the outright skipping of indexation led in some countries

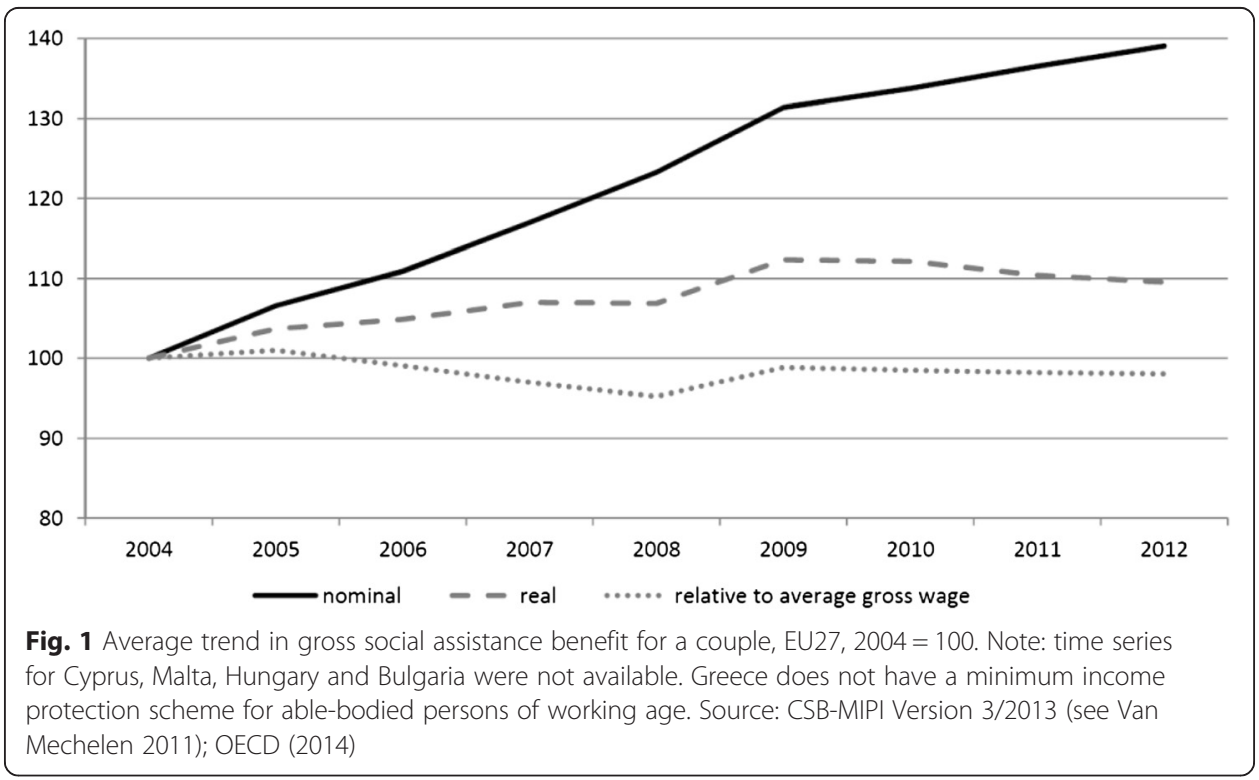


Table 2 Countries introducing measures with a positive effect on dimensions of social citizenship

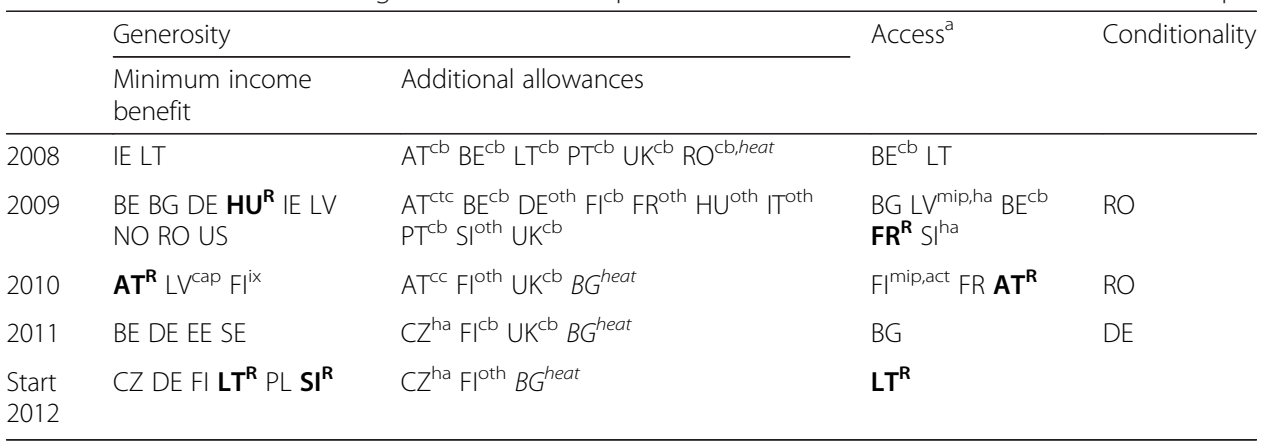

Changes in heating allowance are indicated in italics. Often, these benefits depend on type of heating and will be provided in kind. However, sometimes parameters for access may be tied to gross benefits. DK, LU: n.a. Source: CSB-MIPI Version 3/2013 (Van Mechelen 2011)

$c b$ child-related measure, heat heating allowance, ha housing allowance, oth other, $R$ reform of minimum income scheme, mip minimum income protection, cap benefit cap, ix indexation

${ }^{a}$ Only mentioned where respondent notes actual change

to a small loss in purchasing power. However, bar a few exceptions (most importantly Ireland and Portugal), this decrease does not appear exceptional when compared to pre-crisis trends.

Also relative to average wages, there are no indications for an erosion of benefit levels during the first crisis years, rather the reverse is true. Whereas benefit levels eroded relative to average wages in more than half of the countries in our sample in the years before the crisis, a further erosion of benefits remained very limited in 2008-2009. In line with the deceleration of nominal growth levels, relative benefits did decrease in the majority of countries after 2009, but this erosion remained mostly in line with precrisis annual changes.

All in all, trends in gross social assistance benefit levels prior and during the crisis provide no indications for a retrenchment round immediately after the crisis. Later developments are mainly back in line with pre-crisis trends, with the exception of countries like Portugal and Ireland where gross benefits for a couple have quite substantially decreased.

4.1.1.2 Supplementary allowances and child benefits Minimum income recipients often receive on top of their social assistance benefit child cash benefits and supplementary allowances such as housing or heating allowances, one-off emergency payments etc. To the extent that these additional benefits are not included in the means test, measures impacting on these income components do affect the generosity of the minimum income package, in a few cases even quite substantially.

In Marchal et al. (2014a), we showed that quite a few countries raised the net income of minimum income protection beneficiaries through (a combination of) these additional income components. Some examples include increases of the child benefits or the child-related element in minimum income benefits and crisis-specific supplements in the first years of the crisis (see Table 2).

Additional positive measures become rare as the crisis continues. Reinforcements of the minimum income scheme or child benefits are often no longer (presented as) related to the crisis, but part of reforms prepared before the onset of the crisis (such as 
in Austria); increases following a more prudent policy in the crisis years (Finland, Estonia) or combined with more negative measures, leading to rather mixed effects. For instance, the Slovenian as well as the Lithuanian social assistance reform has got varying effects on different family types, due to changes in equivalence rates. Likewise, the increase in the Austrian child care benefit was coupled to tougher access conditions. Similarly, in the UK, a continued uprating of the child element of the child tax credit was combined with decreases in other elements of this tax credit.

The prevalence of measures that have a (potentially) negative effect on minimum income recipients follows the inverse pattern: whereas negative measures are relatively rare in the first crisis years, they become more and more common as the crisis continues. This is most straightforwardly seen in the change from additional increases of gross minimum income protection benefits in 2009 to the skipping of indexation in a number of countries from 2010 onwards. Also changes in additional allowances indicate that countries implement more measures with a negative impact on minimum income recipients as the crisis advances. In the first crisis years, the only countries negatively impacting on certain income components are Estonia and Latvia. Yet, in 2010, both Ireland and Portugal decrease child-related benefits. In Ireland, the $10 \%$ cut is partially compensated for low income groups. This is however no longer the case when the child benefit is again targeted by cuts in 2011 and 2012. Also in Austria and the UK, child-related payments are reduced. In Hungary, the gas and heating allowance is abolished. One year after it limits access to the social allowance to families with a handicapped child, the Czech Republic completely abolishes this benefit in 2012. In both Italy (Milan) and the UK, the housing allowance scheme became less generous. In the UK, tax credits once again decreased. In Slovenia, it was decided that the indexation of all benefits bar social assistance, would be halted for one and a half year. Moreover, reforms of the minimum income scheme implemented in the later crisis years often have mixed effects. Table 4 shortly describes the main points of the various reforms implemented since the onset of the crisis (up until 2012).

\subsubsection{Access to benefits}

Whereas the generosity of benefits initially increased, Table 2 shows that rules determining access to minimum income schemes and related benefits remained relatively unchanged during the first crisis years.

From 2010 onwards, only Finland and Lithuania introduce measures that are (to some extent) crisis related and that increase access to minimum income or related benefits. In France, the group of persons eligible for minimum income benefits is extended to persons younger than 25 (yet depending on a prior work history) for equity reasons, whereas the Austrian reform renders access criteria more comparable across the Länder. Bulgaria abolishes its time limit within the minimum income scheme in order to bring its legislation in line with the European social charter. In contrast, quite some countries start to reduce access to benefits from 2010 onwards, and often this decision was driven by financial considerations. Examples include the social allowance of the Czech Republic that was from 2011 onwards only awarded to families with a handicapped child, the 2010 Portuguese reform that tightened the means test for minimum income protection and the introduction of a 5-year life time limit for social assistance 
in Spain (Catalonia) in 2012. In addition, one should have lived in Catalonia for 2 years, before being eligible.

All in all, access criteria are more often negatively adjusted than the other way round, especially if we focus on crisis measures. This (as well as the changes in gross benefits that skip indexation or adapt indexation mechanisms and equivalence scales) seems to be in line with the literature on retrenchment, that predicts that unpopular measures will generally be hidden behind rather technical measures, or distinguish between various small groups.

\subsubsection{Obligations: behavioural conditionality}

In Marchal et al. (2014a), we noted the striking absence of crisis-related changes regarding the activity requirements imposed on minimum income protection beneficiaries in the first crisis years. Also later on, changes to activity requirements were generally not framed as crisis measures. Some exceptions include the reforms in Portugal and the Netherlands that increased conditionality (see Table 4) and were (partly) driven by budgetary concerns.

Yet this is not to say that the conditionality of minimum income benefits did not change in the period 2008-2012 (see Tables 2 and 3). However, changes were generally implementations of measures prepared before the onset of the crisis, part of broader policy changes or reforms, or not framed as crisis measures. In Marchal et al. (2014a), we describe the change that occurred in France, the Netherlands, the United Kingdom, Hungary and the Czech Republic in 2008 and 2009. Later on-and quite exceptionally-sanctions for German beneficiaries for minor infringements (such as missing an appointment) were somewhat relaxed. Information on whether or not this was influenced by the crisis is lacking. The United Kingdom continued to roll out a previously decided on measure to gradually move lone parents from income support towards the jobseekers allowance, where they may be faced with tougher activity requirements. Other measures that were implemented, but of which respondents doubt any influence by the crisis are a small increase in the severity of activation-related sanctions in Austria, an increased work requirement and sanctions for mistakes in reporting in Bulgaria, harsher requirements in Finland, increased work requirements in Hungary, more

Table 3 Countries introducing measures with a negative effect on dimensions of social citizenship

\begin{tabular}{|c|c|c|c|c|}
\hline & \multicolumn{2}{|l|}{ Generosity } & \multirow[t]{2}{*}{ Access $^{a}$} & \multirow[t]{2}{*}{ Conditionality } \\
\hline & Minimum income benefit & Additional allowances & & \\
\hline 2008 & & & $B G$ & FR UK \\
\hline 2009 & $C Z P^{i x}$ & $\mathrm{EE}^{\mathrm{cb}} \mathrm{LV}^{\mathrm{cb}} B G^{\text {heat }}$ & $L T^{c b, b} L V H U^{h e a t, b}$ & $\mathbf{F R}^{\mathbf{R}} \mathrm{HU}^{\mathbf{R}} \mathrm{NL}$ UK \\
\hline 2010 & IE IT $\mathbf{P T}^{\mathbf{R}} \mathrm{RO}^{\mathrm{ix}} \mathrm{SI}^{\mathrm{ix}} \mathrm{SK}^{\mathrm{ix}}$ & $\mid E^{c b} P T^{c b}$ & $\begin{array}{l}H U L T^{c b, b} P^{R} A T^{c c, b} \\
I E^{c b}\end{array}$ & $\begin{array}{l}\text { AT BG FI } \mathbf{P T}^{\mathbf{R}} \text { RO } \\
\text { UK }\end{array}$ \\
\hline 2011 & $\begin{array}{l}D E^{i x} E^{c a p} I E P T^{i x} R^{i x} S E^{i x} S K^{i x} \\
U K^{i x}\end{array}$ & $A T^{c b} \mid E^{c b} U K^{c b} H U^{\text {heat }}$ & $A T^{c b} C Z^{c b} R^{m i p, h e a t, b}$ & BG HU SI \\
\hline $\begin{array}{l}\text { Start } \\
2012\end{array}$ & $\begin{array}{l}E S^{i x} H U I T \mathbf{L T}^{\mathbf{R}} \mathrm{PT}^{\mathrm{ix}} \mathbf{R} \mathbf{O}^{\mathbf{R}} \mathbf{S I}^{\mathbf{R}} \mathrm{SK}^{\mathrm{ix}} \\
\mathrm{NL}\end{array}$ & $\begin{array}{l}C Z^{\mathrm{cb}}\left|\mathrm{E}^{\mathrm{cb}}\right| \mathrm{T}^{\mathrm{ha}} \mathrm{SI}^{\mathrm{oth}} \\
\mathrm{UK}^{\mathrm{ha}, \mathrm{cb}}\end{array}$ & $\mathrm{IT}^{\text {ha }} \mathrm{RO} \mathrm{SI}^{\mathbf{R}} \mathrm{ES} \mathrm{LV}$ & $\mathrm{NL}^{\mathrm{R}} \cup \mathrm{K}$ \\
\hline
\end{tabular}

Changes in heating allowance are indicated in italics.

DK, LU: n.a. Source: CSB-MIPI Version 3/2013 (Van Mechelen 2011)

$c b$ child-related measure, heat heating allowance, ha housing allowance, oth other, $R$ reform of minimum income scheme,

mip minimum income protection, cap benefit cap, ix indexation

${ }^{a}$ Only mentioned where respondent notes actual change

${ }^{b}$ Actual impact on minimum income recipients depends on specific situation and interaction with means test for

minimum income protection. Changes to the income threshold/means test for the particular benefit mentioned 
checks of willingness to work in Romania and a tighter suitable employment definition in Slovenia. Also in Slovenia, the 2012 reform introduced activation allowances to minimum income recipients in part time jobs. ${ }^{4}$ Generally, these changes were introduced by referring to the need for activation, and in some cases by a commitment to reducing social fraud.

\subsection{Mixed effects on net income packages}

Figure 2 shows the trends in the simulated net disposable income packages of four hypothetical families from mid-2009 to January $2012 .^{5}$ This period does not entirely coincide with the changes described above nor can standard simulations capture the impact in changes to activity requirements or access conditions. However, as some measures have mixed effects on different types of families, or on different income components, these simulations do provide a more nuanced understanding of trends in overall income packages. In addition, they take account of the diverse impact of the different measures on the final net disposable income.

By far the largest overall nominal decreases are observed in Hungary, Italy, Portugal, Ireland, and, to a more limited extent, in Romania and Lithuania. This mainly reflects the changes these countries introduced to their minimum income schemes. Hungary decreased base rates by around $20 \%$ in 2012, after tightening access for additional adults in a family 2 years earlier. Portugal reformed its minimum income scheme in August 2010, introducing different equivalence rates. In addition, indexation was skipped. In Ireland, we observe the combined impact of subsequent cuts to minimum income benefits and child benefits. The stark decrease of benefits for Italy reflects the aforementioned decreases in both the actually awarded benefits in Milan and the tightened generosity of the regional housing allowance scheme. The decrease of net income packages in Romania is caused by the combination of various retrenchment measures that tightened access to the minimum income benefit and skipped indexation, rather than by the reform described in Table 4 .

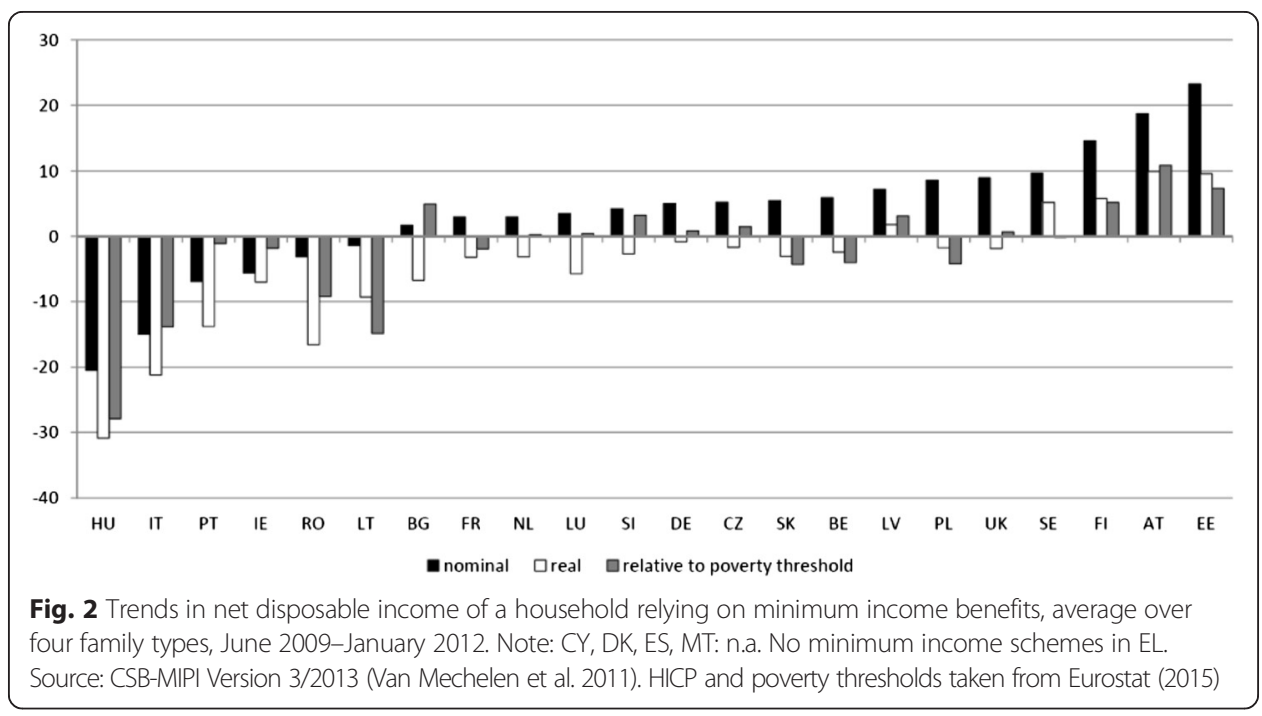


Table 4 Reforms implemented since the onset of the crisis (up to start 2012) Hungary (2009)

The 2009 Hungarian reform (adopted by the parliament on December $15^{\text {th }} 2008$ ) aimed to help long-term unemployed re-enter the labour market (Frey 2011). Therefore, it distinguished between two groups of minimum income beneficiaries, the frail and those able to work. A new benefit was installed for the group deemed able to work, the 'stand by allowance'. The other group remained eligible for regular social assistance. The new stand by allowance is an individual benefit for each eligible adult, regardless of family composition. The individual benefits were higher, whereas work and activity conditions were severely tightened. Moreover, if no jobs are available, (remunerated) community work is offered. The stand by allowance is only payable if no community work can be provided. Since its introduction in 2009, this new scheme was changed on multiple occasions. For instance, from 2010 onwards, only one adult per household was eligible for the stand by allowance. Later, the name of the social assistance benefit changed to 'wage subsidizing benefit' and again to 'employment substitute support', combined with new activity requirements. In January 2012, the standard rate of the benefit was reduced by $20 \%$.

France (2009)

The introduction of the Revenue de Solidarité Active (replacing the former Revenu Minimum d'Insertion and the Allocation de Parent Isolé) aimed to increase work incentives, and to make sure that taking up employment would be financially rewarded. An important element in this respect was the introduction of an earnings disregard of $62 \%$ in the calculation of the new minimum income benefit. In addition, the reform introduced more activation efforts.

Portugal (2010/2011)

The Portuguese reform aimed for a more efficient and effective minimum income scheme (but see Rodrigues 2012). Meanwhile, a number of elements of the reform can be identified as austerity measures necessitated by the crisis context. The main measures include an extension of the income and household concept used for the means test and new (and less generous) equivalence rates. In addition, the complementary support awarded for specific needs was abolished. The conditionality of the minimum income benefit was tightened. Harsher sanctions were introduced, as well as a number of anti-fraud measures (for instance, a false claim excludes one from any means-tested benefit for a 2-year period).

Austria (2010)

The Austrian reform aimed to reduce the differences between the different regional minimum income schemes. An explicit aim was that no beneficiary would lose because of this harmonization. Viennese recipients saw their net income package in fact substantially increase. Main preoccupation was a harmonization of minimum rates and of access conditions. In addition, the reform aimed to facilitate the activation of minimum income beneficiaries by increasing access to public employment services for minimum income recipients.

Netherlands (2012)

The Dutch reform of the minimum income scheme aimed to increase the conditions tied to benefit receipt. Main justifications of the reform were increasing deficits because of the economic crisis, and the perceived need to increase work incentives (Rijksoverheid 2011). The increased conditionality targeted different groups, most importantly lone parents, young jobseekers and artists. In addition, municipalities became entitled to ask for services in return for benefit receipt, even if this did not directly improve prospects for finding employment. The reform also widened the household concept for the means test, yet this measure was revoked a few months later.

Lithuania (2012)

The 2012 changes to the Lithuanian minimum income scheme aimed to make social assistance more effective and just. In addition, work incentives were strengthened. The main changes were to facilitate access to the minimum income scheme, by abolishing the requirement to be a registered unemployed for 6 months prior to being eligible for social assistance. Equivalence scales were adapted, with higher benefit levels for the first member of the family, and lower for the remaining family members. Benefit levels are gradually reduced for long-term beneficiaries. For beneficiaries without children, the benefit can be suspended after 60 months. Former beneficiaries who take up low paid employment can continue to receive part of their benefit as a back to work bonus.

Romania (2012)

Romania introduced a new law on social assistance in 2011 that changed the calculation of minimum income benefits. The benefit levels are from 2012 onwards based on a national reference indicator. Although this will probably result in lower benefits in the longer run, the immediate impact is relatively limited. The aim of the reform is to better target social benefits, and to rationalize (decrease) social expenses. The new law was only partially justified on grounds of the financial crisis.

Slovenia (2012)

The Slovenian reform was already legislated in summer 2010, but due to the crisis actual implementation was delayed until 2012. The changes addressed both the work incentives in the minimum income scheme, as the streamlining of the awarding of means-tested benefits. One of the consequences was a tighter means test (for instance, child benefits are included in the means test, a change that is not completely compensated by the $10 \%$ increase in children's base rates within the minimum income benefit). Also, the definition of a lone parent family was tightened. The reform introduced new equivalence rates that take account of the work effort of beneficiaries. Moreover, the 2010 legislation foresaw a higher standard rate, but due to the crisis, the envisaged increase was only partially implemented. 
In Bulgaria, a nominal standstill since January 2009 resulted in rather substantial real decreases of net income packages. In a large number of countries, we observe a limited real decrease of the net income package in this two and a half-year period. These minor real losses seem to be related to the skipping of indexation, the inadequacy of the indexation mechanism or both.

On the other hand, we see rather stark improvements in Finland, Austria and Estonia. This is mainly due to uprating gross benefit levels over and above inflation. In Finland, this is the result of a conscious effort to reinforce the bottom of the welfare state. In Estonia, the increase occurred after a nominal standstill since the onset of the crisis, and from a low base. The Austrian increase is mainly due to the 2010 reform that raised benefit levels for Viennese beneficiaries.

All in all, bar a number of important exceptions at either side of the spectrum, in the brunt of countries minimum income protection beneficiaries only experienced rather limited real decreases. This is partially because of the time frame, that does not include some of the expansionary measures introduced at the start of 2009 and only covers two and a half years, partly because some measures (e.g. changing indexation mechanisms in Germany and the United Kingdom, different calculation methods in Romania) will only reveal their full impact in the longer run, partly because changes were not quite that pronounced in a number of countries (at least not for these particular family types) and partly because the average obfuscates the impact of some policy changes on a limited number of family types.

Figure 3 illustrates the varying impact of some of these policy changes to families with and families without children. Especially in Hungary, families without children were most severely hit by the policy change that only one adult per family is entitled to social assistance for able-bodied persons of working age. In addition, they also suffered from the 2012 decrease of the minimum income benefit. For the other family types, this has been partially cushioned by protective clauses for children.

For singles and couples with two children aged 7 and 14, we notice the harsh impact of the new equivalence rates in Lithuania, Slovenia and to a more limited extent also in Portugal. In all three countries, larger families experienced larger real decreases than childless singles or couples. In Romania, the inclusion of the means-tested child benefit in the means test has important consequences, causing a real drop of over $20 \%$ in net disposable income for families with children, as opposed to a real decrease of $7 \%$ for couples without children. In Sweden on the other hand, benefit rates for children increased rather substantially in order to bring legislation in line with changes in the housing allowance scheme.

\section{Discussion}

How does this all add up? Figure 4 shows the number of countries implementing positive and/or negative measures in the period 2008-start 2012. We see a shift from an emphasis on positive measures in 2008 and 2009 to a focus on more negative measures in a substantial number of countries from 2010 onwards.

This pattern is more pronounced for some aspects of social citizenship than for others and especially outspoken for changes to the standard rates of minimum income benefits (MIP in Fig. 4). Whereas declines in standard rates are virtually absent in 2008 and 2009, nine countries issue increases in 2009. To some extent, this is in countries 


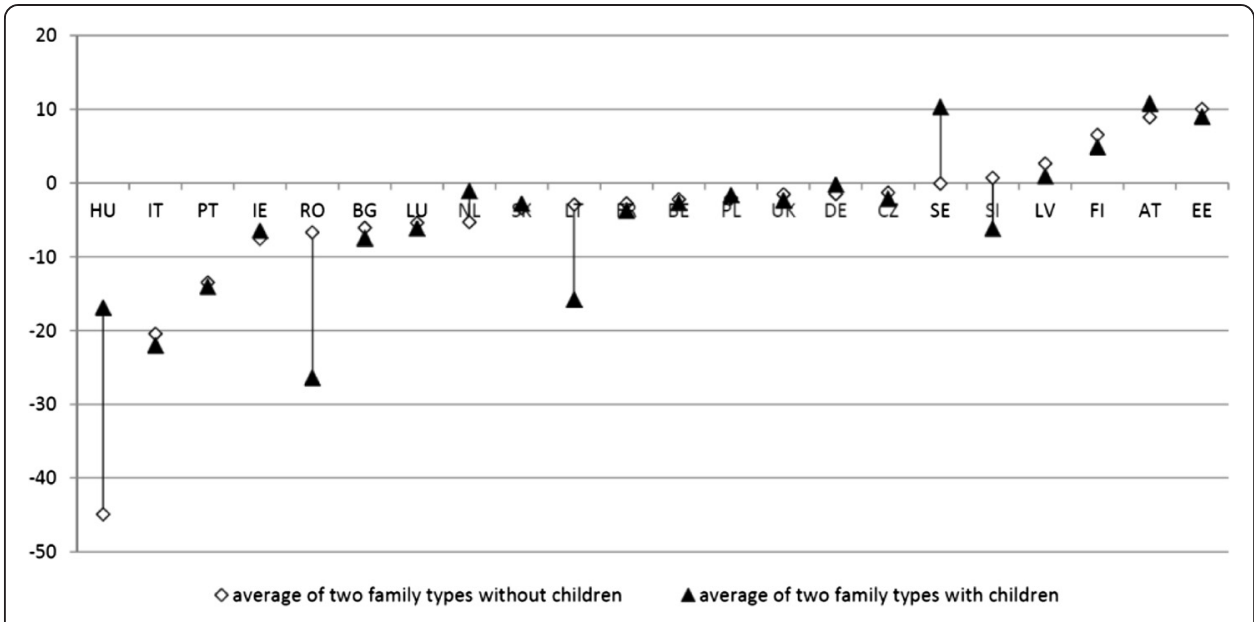

Fig. 3 Real trends in net disposable income of a household relying on minimum income benefits, averages of family types with and without children, June 2009-January 2012. Note: see note to Fig. 2. Source: CSBMIPI Version 3/2013(Van Mechelen et al. 2011), HICP from Eurostat (2015)

where an adequate indexation mechanism is lacking, but also other countries chose to increase gross benefits over and above indexation. Later on, these additional increases become rare. In addition, from 2010 onwards, more and more countries take measures that have a negative impact on minimum income benefits.

Also additional allowances were increased in the first crisis years. Often, these were increases of child-related benefits, or actual one-off crisis premiums. Again from 2010 onwards, additional increases become less common and (some) negative measures start to appear.

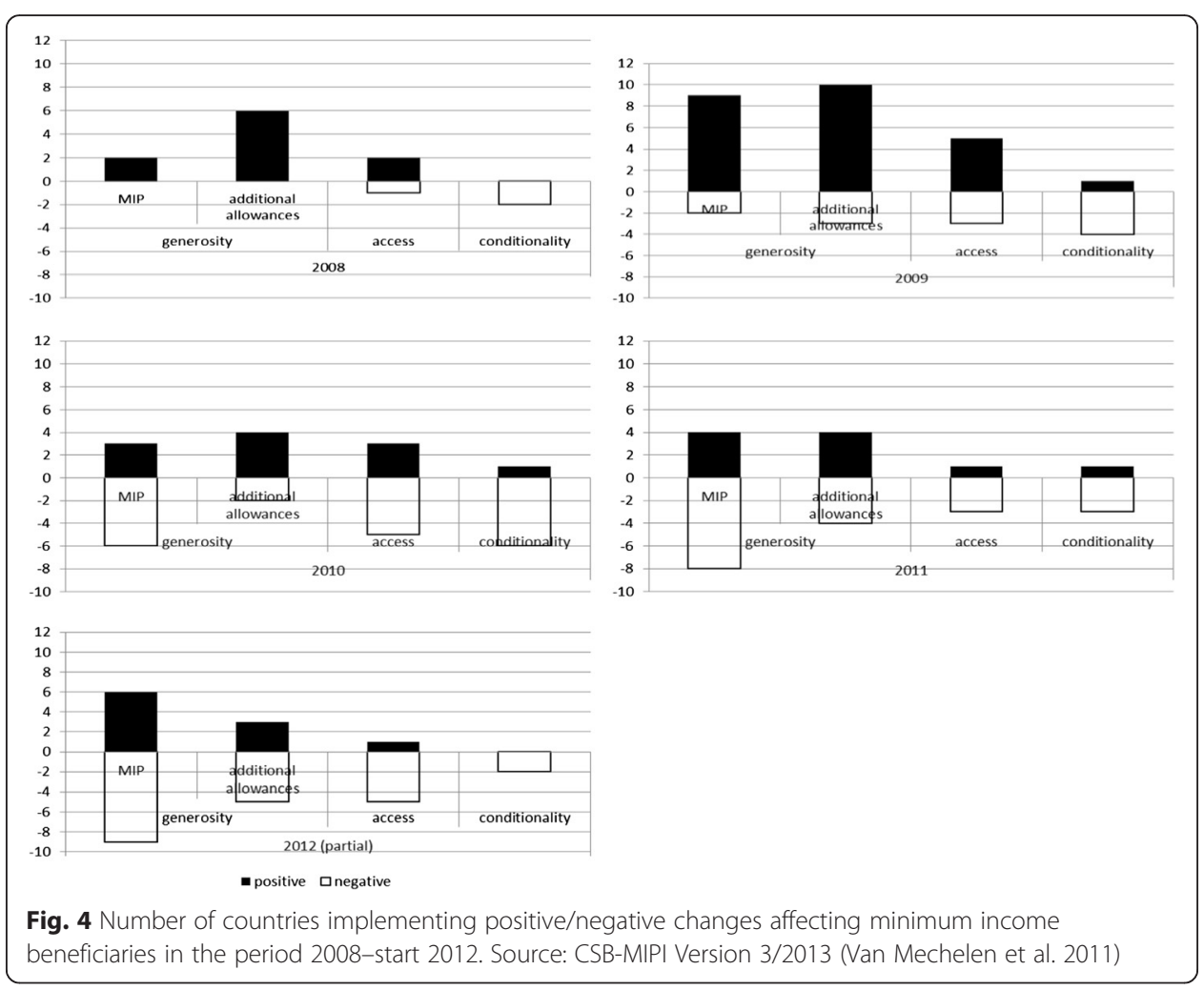


The pattern is somewhat different for access conditions. It seems that only rarely governments sought to pursue an expansionary policy by increasing the pool of possible beneficiaries of minimum income benefits or relevant additional allowances. Some countries did tighten access conditions to additional benefits or the minimum income protection scheme as part of an austerity strategy from 2009 and 2010 onwards. It is however not very clear what the impact is on the pool of eligible persons.

Finally, Fig. 4 shows that changes to behavioural conditionality related to minimum income receipt do not follow this expansion-retrenchment pattern at all. This is mainly because crisis measures generally did not impact on conditionality. Governments did increase investments in activation programs, but the actual conditions tied to minimum income receipt were mainly left unchanged by crisis responses. Measures that were prepared before the onset of the crisis were however implemented. In line with trends prior to the crisis (Weishaupt 2013), these measures generally tightened conditionality.

Interestingly, most of the negative changes introduced in the period 2008-start 2012 are technical in nature. This is most clearly seen in the changes to MIP standard rates from 2010 onwards. Whereas the positive changes in 2009 were increases of standard rates, actual nominal decreases are very rare. Rather, governments introduced measures such as the skipping of indexation for inflation, changing the indexation mechanism or the introduction of a benefit cap. When nominal benefit rates did decrease, this was generally in the context of broad reforms that introduced new equivalence rates with different consequences for particular family types. In this regard, it is also noteworthy that the rather technical and invisible access conditions were often not loosened in the first crisis, yet they were tightened in a number of countries from 2009 onwards.

Our findings contribute to a number of additional issues raised in the literature. For one, it is clear that the small increases observed right after the onset of the crisis did not translate in higher minimum income protection packages. In fact, the austerity tide-although perhaps less severely than feared-has impacted on minimum income schemes in quite a number of countries. In order to shed light on theoretical questions whether minimum income schemes are more vulnerable to these retrenchment measures than contributory-based income replacement schemes (Korpi and Palme 1998; Pierson 1994; Nelson 2007), a more complete comparison to changes in unemployment insurance schemes would be needed.

Second, Figs. 2 and 3 show a wide variation in the size (and direction) of changes to the generosity of social floors. Whereas a study of the determinants of the direction of crisis-induced change is outside the scope of this article, a cursory reading of Fig. 2 does seem to corroborate findings by Shahidi (2015) and Armingeon (2012) on the primacy of fiscal considerations over and above 'traditional' explanations, such as the left-right inclination of the government and institutional factors. We do indeed observe the largest decreases in countries where the crisis has hit hard, most importantly Ireland, Portugal, Hungary and Italy. Yet there are some exceptions, and in future research, we aim to look further into the combination of factors explaining variation in crisis and austerity reactions in the field of minimum income protection.

Third, a number of authors have raised the question whether crisis-induced change opens up a window of opportunity to change the course of path-trapped social security schemes (Starke et al. 2013; Castles 2010). Our focus on minimum income schemes, that are relatively easy to alter, does not allow us to derive stark conclusions regarding 
this conjecture. Nonetheless, most measures that affected social citizenship taken after the onset of the crisis were rather incremental. Potentially some of the austerity measures implemented from 2010 onwards will in the longer run substantially impact on the final safety net. For instance, changing indexation parameters will likely result in less generous benefits (Joyce and Levell 2011). Some countries did introduce measures coined by respondents or national sources as reforms. A rather common characteristic of these reforms is their focus on increasing conditionality and financial work incentives. This focus does not seem out of line with the pre-crisis trend towards increased conditionality and activation efforts (Eichhorst and Konle-Seidl 2008; Weishaupt 2013). Yet other reform measures, especially changing equivalence scales and tightened access criteria, generally introduce rather profound changes with regard to the other social citizenship dimensions presented above. It remains however difficult to assess whether these changes were triggered by the crisis or not.

\section{Conclusions}

Social safety net provisions in Europe had generally suffered two decades of relative neglect and erosion prior to the crisis, legitimized by the idea that work and not welfare was the best protection against poverty. The result was that minimum income protection levels were at levels considerably below widely used adequacy benchmarks, including the EU's own $60 \%$ of national median equivalent disposable income threshold.

The crisis smashed the notion that people capable for work ought to be able to make a decent living if they are doing enough to find and accept work. The initial phase of the crisis did indeed trigger some changes for the better-expansionary and supportive measures were the general pattern. But as this paper shows, these changes proved short-lived. Retrenchment measures become evident later on in a substantial number of countries. Whereas the expansionary measures observed in the first crisis years generally centred on increases in benefits, retrenchment measures were more often enacted through more technical changes. Examples include as follows: skipping indexation, tightening the means test, abolishment or decrease of additional benefits (for instance child benefits). Few countries actually cut minimum income benefits. Moreover, with the exception of Hungary and Ireland, cuts were mainly part of a more encompassing reform that changed base rates as well as equivalence rates. This is broadly in line with the retrenchment literature where it is argued that retrenchment is often pursued through less visible, apparently technical changes.

The long-term impact of these technical changes is hard to predict. For now, time series and standard simulations of changes in net disposable income packages show relatively modest impacts in the period 2009-2012. Yet some of the technical changes may carry the seeds for an incremental path departing process, such as new, less generous indexation mechanisms or different equivalence scales. These changes may have far-reaching implications in the longer run, although their immediate impact is rather modest, not in the least because they may impact on the notion of what a social floor should actually entail. Nonetheless, in some countries, such as Hungary, Italy, Portugal and Romania, the combined effect of various retrenchment measures already now weighs heavily on minimum income beneficiaries.

An important common denominator of the reforms enacted in the wake of the crisis was the attention to behavioural conditionality requirements. This focus reaffirms a 
policy trend apparent in the pre-crisis years, but in a largely different macro-economic context.

An open question for further research is how this focus on activation will impact on the situation of minimum income recipients in a context that starkly differs from the pre-crisis employment high.

This is all the more relevant as we possibly have not yet seen the end of retrenchment in social protection schemes in Europe. The UK government for example recently announced cuts to the Universal Credit-the main income protection scheme for ablebodied persons of working age, be it in or out of work. Budgetary concerns where a stated motive. Similarly, only a couple of months after the implementation of the Portuguese 2010/2011 reform, the Portuguese government implemented a further tightening of equivalence scales within the minimum income scheme. Other countries have announced changed to minimum income schemes. In this regard, the description of policy reforms provided in this article, may serve as a cautionary tale: the common denominator of most reforms were an increased focus on activity requirements, coupled to a focus on savings and stricter equivalence scales.

The obvious fact that minimum income schemes are considered a viable target for austerity measures by national governments is all the more disquieting as social floors within the EU were largely below the poverty threshold to begin with. This stands in stark contrast to the calls by both the European Commission (2008) and the International Labour Organization to ensure adequate social floors (International Labour Organization, 2012). Whereas the continued focus on work incentives and activity requirements by the national governments could to some extent be considered in line with these organizations' concern about well-functioning labour markets and unemployment, the inadequate benefit levels and restricted access conditions are not.

\section{Endnotes}

${ }^{1}$ EU27 excluding Cyprus and Malta. No information available for Denmark. In Greece, no minimum income scheme for the able bodied of working age currently exists.

${ }^{2}$ More in particular, standard simulations cover the income situation of a single, a couple, a couple or a lone parent with two children aged 7 and 4, and a lone parent with a young child.

${ }^{3} \mathrm{~A}$ list of the names of the benefit schemes covered is provided in Van Mechelen and Marchal (2013).

${ }^{4}$ Both the Slovenian as the Czech activation-related changes to minimum income benefits were already included under changes in minimum income benefits.

${ }^{5}$ A 35-year old able-bodied single minimum income recipient, no own income; couple without children, couple with two children, aged 7 and 14; lone parent with two children, aged 7 and 14.

Competing interests

The IZA Journal of European Labor Studies is committed to the IZA Guiding Principles of Research Integrity. The authors declare that they have observed these principles. 


\section{Acknowledgements}

SM gratefully acknowledges a PhD scholarship from the Research Foundation Flanders. The authors would like to thank the participants of the ECPR General conference (Bordeaux, 5-7 September 2013) and the ESA Crisis, Critique and Change conference (Turin, 28-31 August 2013) for helpful suggestions and comments. The authors are solely responsible for any remaining shortcomings and errors.

Responsible editor: Kahanec

\section{Author details}

${ }^{1}$ Sint-Jacobstraat 2, M171, 2000 Antwerp, Belgium. ${ }^{2}$ Sint-Jacobstraat 2, M181, 2000 Antwerp, Belgium. ${ }^{3}$ Sint-Jacobstraat 2, M178, 2000 Antwerp, Belgium.

Received: 10 April 2015 Accepted: 5 January 2016

Published online: 25 February 2016

\section{References}

Armingeon K (2012) The politics of austerity: what political parties can do and what markets want. Paper presented at the 2012 meeting of the American political science association, New Orleans, 30.08.2012-02.09.2012

Aurich P (2011) Activating the unemployed_directions and divisions in Europe. Eur J Soc Secur 13(3):294-316

Bahle T, Hubl V, Pfeifer M (2011) The last safety net. A handbook of minimum income protection in Europe. Policy Press, Bristol

OECD (2011) Benefits and wages: country specific files. http://www.oecd.org/els/soc/benefits-and-wages-countryspecific-information.htm. Accessed 4 Aug 2011

Bradshaw J, Finch N (2002) A comparison of child benefit packages in 22 countries. Research Report. UK Department for work and pensions, Norwich

Castles FG (2010) Black swans and elephants on the move: the impact of emergencies on the welfare state. J Eur Soc Policy 20:91-101

Chung $\mathrm{H}$, Thewissen S (2011) Falling back on old habits? A comparison of the social and unemployment crisis reactive policy strategies in Germany, the UK and Sweden. Soc Policy Admin 45(4):354-370

Clasen J, Clegg D (2007) Levels and levers of conditionality: measuring change within welfare states. In: Clasen J, Siegel NA (eds) Investigating welfare state change. The 'dependent variable problem' in comparative analysis. Edward Elgar, Cheltenham, pp 166-197

Clasen J, Clegg D (eds) (2011) Regulating the risk of unemployment. Oxford University Press, Oxford

Clasen J, Clegg D, Kvist J (2012) European labour market policies in (the) crisis. ETUI Working Papers, ETUI, Brussels MISSOC (2013) Comparative Tables Database 2013 http://missoc.org/MISSOC/comparativeTables. Accessed 12.10.2012

Dolls M, Fuest C, Peichl A (2012) Automatic stabilizers and economic crisis: US vs Europe. J Pub Econ 96(3):279-294

Eardley T, Bradshaw J, Ditch J, Gough I, Whiteford P (1996) Social assistance in OECD countries: synthesis report. Research Report. HSMO Department of social security, London

Eichhorst W, Konle-Seidl R (2008) Contingent convergence: a comparative analysis of activation policies. IZA Discussion Paper, IZA, Bonn

European Commission (2008) Communication from the commission to the European council-a European Economic Recovery Plan. European Commission, Brussels

Eurostat (2015) Statistics by theme. http://ec.europa.eu/eurostat/web/income-and-living-conditions/data/database. Accessed May 2015

Farnsworth K, Irving Z (eds) (2011) Social policy in challenging times. Economic crisis and welfare systems. The Policy Press, Bristol

Frey M (2011) The legal and institutional environment of the Hungarian labour market. In: Fazekas K, Molnar G (eds) The Hungarian labour market: review and analysis 2011. Institute of Economics, IE HAS \& National Employment Foundation, Budapest, pp 211-239

Gauthier AH (2010) The impact of the economic crisis on family policies in the European Union. European Commission, DG Employment, Social Affairs and Equal Opportunities, Brussels

Gough I (2011) From financial crisis to fiscal crisis. In: Farnsworth K, Irving Z (eds) Social policy in challenging times. Economic crisis and welfare systems. The Policy Press, Bristol, pp 49-64

Hemerijck A (2012) Stress-testing the new welfare state. In: Bonoli G, Natali D (eds) The politics of the new welfare state. Oxford University Press, Oxford, pp 68-90

ILO/World Bank (2012) The ILO/World Bank inventory of policy responses to the global financial and economic crisis of 2008 http://www.lo.org/dyn/crisis-inventory/f?p=17030:2:2052679726638659. Accessed Jul 2013.

Immervoll H (2012) Minimum-income benefits in OECD countries. In: Besharov D, Couch K (eds) Counting the poor: new thinking about European poverty measures and lessons for the United States. Oxford University Press, Oxford

International Labour Organization (2012) Recommendation concerning National Floors of Social Protection. 202, vol 202. International labour organization, Geneva

International Labour Organization, World Bank (2012) Joint synthesis report: inventory of policy responses to the financial and economic crisis. ILO/World Bank, Washington/Geneva

International Monetary Fund (2012) Greece: request for extended arrangement under the extended fund facility—staff report. IMF Country Report. International Monetary Fund, Washington

Isik-Dikmelik A (2012) Do social benefits respond to crises? Social Protection and Labor Discussion Paper. World Bank, Washington

Jenkins SP, Brandolini A, Micklewright J, Nolan B (eds) (2013) The great recession and the distribution of household income. Oxford University Press, Oxford

Joyce R, Levell P (2011) The impact in 2012-2013 of the change to indexation policy. IFS Briefing Note No. 120. Institute for Fiscal Studies. 
Kenworthy L (2010) Labour market activation. In: Castles FG, Leibfried S, Lewis J, Obinger H, Pierson C (eds) The Oxford handbook of the welfare state. Oxford University Press, Oxford, pp 435-447

Korpi W (1980) Social policy and distributional conflict in the capitalist democracies. A preliminary comparative framework. West Eur Polit 3(3):296-316

Korpi W, Palme J (1998) The paradox of redistribution and strategies of equality: welfare state institutions, inequality, and poverty in the Western countries. Am Sociol Rev 63(5):661-687. doi:10.2307/2657333

Kvist J (2007) Exploring diversity: measuring welfare state change with fuzzy-set methodology. In: Clasen J, Siegel NA (eds) Investigating welfare state change: the dependent variable problem in comparative analysis. Edward Elgar, Cheltenham, pp 198-214

Marchal S, Van Mechelen N (2014b) A new kid in town? Active inclusion in European minimum income schemes. Improve Working Paper Series. Herman Deleeck Centre for Social Policy, Antwerp

Marchal S, Marx I, Van Mechelen N (2014a) The Great wake-up call? Social citizenship and minimum income provisions in Europe in times of crisis. J Soc Policy 43(2):247-267. doi:10.1017/S0047279413000950

Marshall TH (1950) Class, citizenship and social development. Harvester Wheatsheaf, New York

Nelson K (2007) Universalism versus targeting: the vulnerability of social insurance and means-tested minimum income protection in 18 countries, 1990-2002. Int Soc Secur Rev 60(1):33-58

OECD Stat.Extracts (2014) http://stats.oecd.org/index.aspx?queryid=35253\#. Accessed November 2014

Pierson P (1994) Dismantling the welfare state? Reagan, Thatcher, and the politics of retrenchment. Cambridge University Press, Cambridge

Pierson P (1996) The new politics of the welfare state. World Polit 48(2):143-179

Rijksoverheid (2011) Kabinet scherpt bijstand aan. http://www.rijksoverheid.nl/onderwerpen/bijstand/nieuws/2011/04/ 08/kabinet-scherpt-bijstand-aan.html. Accessed 20.62011

Rodrigues CF (2012) Minimum Income in Portugal: Changing the Rules in Times of Crisis. Working Paper No. 05/2012/ DE/CEMAPRE. Lisbon: School of Economics and Management, technical university of Lisbon

Shahidi FV (2015) Welfare capitalism in crisis: a qualitative comparative analysis of labour market policy responses to the Great Recession. J Soc Policy 44(4):659-686

Spilimbergo A, Symansky S, Blanchard O, Cottarelli C (2008) Fiscal policy for the crisis. IMF Staff Position note, IMF

Starke P, Kaasch A, Van Hooren F (2013) The welfare state as crisis manager. Responses to major economic crisis in small open economies. Palgrave MacMillan, Basingstokes

Van Mechelen N, Marchal S (2013) Struggle for life: social assistance benefits, 1992-2009. In: Marx I, Nelson K (eds) Minimum income protection in flux. Work and welfare in Europe. Palgrave Macmillan, Houndmills, pp 28-53

Van Mechelen N, Marchal S, Goedemé T, Marx I, Cantillon B (2011) The CSB Minimum Income Protection Indicators dataset (CSB-MIPI). CSB Working Paper. Herman Deleeck Centre for Social Policy, Antwerp

Vis B, van Kersbergen K, Hylands T (2011) To what extent did the financial crisis intensify the pressure to reform the welfare state? Soc Policy Admin 45(4):338-353

Weishaupt T (2013) Origin and genesis of activation policies in 'old' Europe: towards a balanced approach? In: Marx I, Nelson K (eds) Minimum income protection in flux. Palgrave Macmillan, Hampshire, pp 190-216

Yerkes M, van der Veen R (2011) 'Crisis and welfare state change in the Netherlands'. Soc Pol \& Admin 45(4):430-444.

\section{Submit your manuscript to a SpringerOpen ${ }^{\mathcal{O}}$} journal and benefit from:

- Convenient online submission

- Rigorous peer review

- Immediate publication on acceptance

- Open access: articles freely available online

- High visibility within the field

Retaining the copyright to your article

Submit your next manuscript at $\boldsymbol{s p r i n g e r o p e n . c o m ~}$ 